\title{
ANALISIS DAYA TAMPUNG KALI FERMAI DI KOTA SORONG
}

\author{
Ahmad Azhar Basyir \\ Program Studi Teknik Sipil Universitas Muhammadiyah Sorong \\ Jalan Pendidikan No 27 Kota Sorong, Propinsi Papua Barat \\ Email:Achiel.imm@gmail.com
}

\begin{abstract}
ABSTRAK
Kota Sorong merupakan wilayah daratan yang membentang sepanjang pesisir Propinsi Papua Barat. Salah satunya adalah kali fermai di kelurahan malawele, yang mana sampai saat ini merupakan salah satu jalur air. Tujuan penelitian ini yaitu untuk menganalisa kapasitas kali yang terjadi di wilayah Kota Sorong.Metode penelitian yang digunakan adalah dengan melakukan pengamatan secara langsung serta terhadap muara sungai yang ada di Kota Sorong.
\end{abstract}

Kata Kunci : analisis; kali; daya tampung 


\section{PENDAHULUAN}

\section{Latar Belakang}

Kota Sorong merupakan wilayah yang membentang sepanjang pesisir bagian barat Propinsi Papua Barat. Salah satunya adalah muara Sungai Remu, yang mana sampai saat ini merupakan salah satu media transportasi laut dimana kapal-kapal masyarakat maupun nelayan keluar masuk.Muara sangat terpengaruh oleh kondisi air daratan seperti aliran air tawar dan sedimen, serta air lauatan seperti pasang -surut, gelombang, dan masuknya air asin.Proses sedimen terjadi karena banyak penyebabnya saat musim hujan dan debit air megalami kenaikan dan akan terjadi luapan air sungai ( banjir ).Dalam situasi tersebut kecepatan aliran air luapan ( banjir ) sungai akan mengalami penurunan karena terambat oleh berbagai pematang - pematang, arus dan gelombang laut . Maka akan terjadi proses pelumpuran atau pegendapan material sedimen di kawasan muara sungai tersebut .

\section{Tujuan Penelitian}

Penelitian ini bertujuan untuk menganalisa daya tamping kali untuk 5 sampai 10 tahun yang akan datang.

\section{STATE OF THE ART}

Adapun penelitian terdahulu yang terkait dengan penelitian ini adalah sebagai berikut :

1. Menurut Maulidya, I., Karnaningroem, N., \& FTSP-ITS, J. T. L. (2009) mengatakan bahwa dari hasil penelitian diketahui bahwa daya dukung Kali Surabaya segmen Gunungsari - Jagir telah terlampaui hingga $384.677,13 \mathrm{~kg} / \mathrm{hari}$ akibat besarnya beban pencemaran yang dibuang ke dalamnya. Daya tampung Kali Surabaya pun telah terlampaui akibat defisit oksigen yang terjadi setelah percampuran point source I, II, dan III melebihi defisit oksigen yang diperbolehkan $(1,62 \mathrm{mg} / \mathrm{l})$. Oleh karena itu, beban pencemaran yang dibuang ke Kali Surabaya segmen Gunungsari - Jagir perlu diminimisasi menjadi 0 kg/hari. Hal ini dapat dilakukan dengan mengolah limbahnya terlebih dahulu sebelum membuangnya ke badan air.

2. Menurut Abdi, Z., Hadi, M. P., \& Widiyastuti, M. (2011) mengatakan bahwa berdasarkan hasil penelitian, total beban pencemaran BOD, COD dan TSS berturut-turut sebesar 14,463; 43,363; 14,658 Ton/jam dengan daya tampung beban pencemaran berturut- turut sebesar 22,956; 108,6; 33,2 Ton/jam. Walaupun secara total daya tampung beban pencemaran belum terlampaui, namun jika ditinjau berdasarkan penggalpenggal sungai (reach), kelebihan beban pencemaran BOD telah terjadi di Sungai Pangian sebesar 0,16 Ton/jam, beban pencemaran COD pada kilometer 140 - 139 sebesar 14,58 Ton/jam dan beban pencemaran TSS pada kilometer 156 - 141 sebesar 61,2 Ton/jam. Uji reliabilitas dengan relative bias dan mean relative error menunjukkan bahwa pemodelan dengan metode QUAL2Kw dapat diterima penggunaannya di daerah penelitian, namun uji korelasi pada grafik pencar menunjukkan model hanya berlaku pada satu set data pemantauan saja. Hasil pemodelan hanya mewakili daya tampung beban pencemaran sesaat.

3. Menurut Irsanda, P. G. R., Karnaningroem, N., \& Bambang, D. (2014) mengatakan bahwa Berdasarkan perhitungan daya tampung beban pencemaran maka didapatkan daya tampung maksimum dan daya tampung minimum pada tiap segmen. Hasil dari aplikasi dan evaluasi dengan Qual2kw pada Kali Pelayaran dalam kondisi telah tercemar.

4. Menurut Sahabuddin, H., Harisuseno, D., \& Yuliani, E. (2014) mengatakan bahwa Parameter TDS, TSS, COD dan BOD yang mengalami peningkatan setiap tahun. Penetapan status mutu air di Sungai Wanggu merupakan tahapan yang penting, dengan menggunakan Metode STORET, Sungai Wanggu mengalami cemar berat dan metode Indeks Pencemaran mengalami cemar sedang. Untuk perhitungan Daya Tampung Beban Pencemaran di Sungai Wanggu tidak mempunyai daya tampung lagi untuk penambahan parameter BOD maka diperlukan strategi pengendalian pencemaran air. Sungai Wanggu yang berpotensi sebagai sumber air baku dapat dimanfaatkan sebagai sumber air bersih bagi penduduk kota Kendari kedepan.

\section{METODE}

\section{Tahapan Penelitian}

Tahapan penelitian yang digunakan adalah sebagai berikut :

1. Melakukan pengamatan terhadap lokasi yang akan ditinjau.

2. Melakukan persiapan alat-alat yang akan digunakan untuk pengukuran.

3. Melakukan pengukuran sebelum hujan

4. Melakukan pengukuran pasca penelitian 
5. Kesimpulan dan saran

Semua metode penulisan dan analisa dalam artikel ilmiah ini merujuk pada panduan penulisan tugas akhir Fakultas Teknik Universitas Muhammadiyah Sorong tahun 2014 (Pristianto, Amri, \& Rusdi, 2014).

\section{REFERENSI}

1. Abdi, Z., Hadi, M. P., \& Widiyastuti, M. (2011). Kajian Daya Tampung Beban Pencemaran Sungai Batanghari Pada Penggal Gasiang-Sungai Langkok Sumatera Barat. Majalah Geografi Indonesia, 25(1), 70-94.

2. Irsanda, P. G. R., Karnaningroem, N., \& Bambang, D. (2014). Analisis Daya Tampung Beban Pencemaran Kali Pelayaran Kabupaten Sidoarjo Dengan Metode Qual2kw. Jurnal Teknik ITS, 3(1), D47-D52.

3. Maulidya, I., Karnaningroem, N., \& FTSP-ITS, J. T. L. (2009). Studi Daya Dukung dan Daya Tampung Kali Surabaya Segmen Gunungsari-Jagir Dengan Metode Linear Programming. Skripsi. Tidak dipublikasikan. Surabaya: Jurusan Teknik Lingkungan FTSP ITS.

4. Pristianto, H., Amri, I., \& Rusdi, A. (2014, May 9). Pedoman Penulisan Tugas Akhir Fakultas Teknik Universitas Muhammadiyah Sorong 2014. http://doi.org/10.17605/OSF.IO/4VTJM.

5. Sahabuddin, H., Harisuseno, D., \& Yuliani, E. (2014). Analisa status mutu air dan daya tampung beban pencemaran Sungai Wanggu Kota Kendari. Jurnal Teknik Pengairan, 5(1), 19-28. 